\title{
Erysiphe paradoxa: A Newly Reported Powdery Mildew on Acer monspessulanum in Turkey
}

\author{
Şanlı KABAKTEPE ${ }^{1} \oplus$, Ilgaz AKATA ${ }^{2 *}$, Mustafa SEVINDIIK ${ }^{3} \bullet$ \\ ${ }^{1}$ Malatya Turgut Ozal University, Battalgazi Vocational School, Battalgazi, Malatya, TURKEY \\ ${ }^{2}$ Ankara University, Faculty of Science, Department of Biology, Ankara, TURKEY \\ ${ }^{3}$ Osmaniye Korkut Ata University, Bahçe Vocational School, Department of Food Processing, \\ Osmaniye, TURKEY \\ "Corresponding Author: fungus@ hotmail.com.tr
}

Received Date: 20.07.2020

Accepted Date: 28.09 .2020

\section{Abstract}

Aim of the study: The current study aims to contribute Turkish powdery mildews by adding newly recorded fungus.

Area of study: The northern slopes of Derebağ waterfall was the study area located within the borders of Derebağ Town (Yahyalı/Kayseri/Turkey) district in the northeast of Aladağlar.

Material and methods: Infected maple specimens were collected from the field on October 14, 2015 and brought the laboratory for identification studies. Morphological structures were examined using both simple light microscope and scanning electron microscope (SEM). The identified samples were deposited in Inonu University Herbarium (INU).

Main results: Erysiphe paradoxa was recorded for the first time from Turkey.

Highlights: Erysiphe paradoxa was reported on Acer monspessulanum. E. paradoxa was a new record for Turkish powdery mildews. E. paradoxa samples collected from Turkey were the third report in the World.

Keywords: Acer, Powdery Mildews, New Record, Turkey

\section{Erysiphe paradoxa: Türkiye'de Acer monspessulanum Üzerinde Tespit Edilen Yeni Bir Külleme Kaydı}

\footnotetext{
Öz

Çalışmanın amacı: Mevcut çalışma, Türkiye küllemelerine yeni bir kayıt ilave ederek katkıda bulunmayı amaçlamıştır.

Çalışma alanı: Çalışma alanı olan Derebağ şelalesinin kuzey yamaçları, Aladağlar'ın kuzeydoğusunda Derebağ Kasabası (Yahyalı / Kayseri/Türkiye) sınırları içerisinde yer alır.

Materyal ve yöntem: Enfekte akçaağaç örnekleri araziden 14 Ekim 2016 tarihinde toplanmıştır ve teşhis çalışmaları için laboratuvara getirilmiştir. Morfolojik yapılar hem basit ışık mikroskobu hem de taramalı elektron mikroskobu (SEM) kullanılarak incelenmiştir. Teşhis edilen örnekler İnönü Üniversitesi Herbaryumunda (INU) saklanmaktadır.

Temel sonuçlar: Erysiphe paradoxa Türkiye için yeni kayit olarak verilmiştir.

Araşttrma vurguları: Erysiphe paradoxa, Acer monspessulanum üzerinden rapor edilmiştir. E. paradoxa Türkiye için yeni kayıt olarak kaydedilmiştir. Türkiye'den toplanan E. paradoxa örnekleri, dünyadan üçüncü rapor olarak bildirilmiştir.
}

Anahtar Kelimeler: Acer, Küllemeler, Yeni Kayıt, Türkiye

\section{Introduction}

Erysiphales, also known as powdery mildews, is a widely distributed order, which includes 873 species belonging to 16 genera within the family Erysiphaceae. Its members are plant pathogens infecting approximately 10.000 Angiosperms species worldwide and causing fungal diseases on various cultivated and wild plants. Although they are cosmopolitian and distributed from tropics to the polar areas, powdery mildews are mainly distributed in the north temperate zone (Braun, 1987; Kabaktepe et al., 2015).

Erysiphe is the largest genus of the family Erysiphaceae and it contains roughly 450 species. Chasmothecia including multiple asci 
and mycelioid appendages are the main characteristics of the genus, whose definition and the members have been dramatically revised based on morphological and molecular phylogenetic data. Currently, members of the genus consist of five morphological sections (Erysiphe, Microsphaera, Uncinula, Typhulochaeta, Californiomyces) that are separated from each other by different morphologies of their sexual structures (Braun \& Takamatsu, 2000; Abasova et al., 2018).

Erysiphe paradoxa (Simonyan) U. Braun \& S. Takam. collected in Armenia on Acer monspessulanum subsp. ibericum

(M.Bieb. ex Willd.) Yalt. was identified by Simonyan (1959) as Uncinula paradoxa. In 2000, U. paradoxa was reported from Iran on Acer hyrcanum Fisch. \& C.A.Mey. and A. monspessulanum L. (Tavanaei et al., 2000; Khodaparast \& Abbasi, 2009). Later, Uncinula was considered as one of the five section of the genus Erysiphe DC, and the new and current name Erysiphe paradoxa was published as a new combination (Braun \& Takamatsu, 2000).

According to literature on Turkish powdery mildews (Akata \& Heluta, 2015; Kabaktepe et al., 2015; Kabaktepe \& Akata 2016; Heluta et al., 2017; Churakov et al., 2018; Akata et. al., 2019; Kabaktepe \& Akata, 2019; Akdeniz \& Sert, 2019), 146 species has been recorded so far. Among them, 48 species belong to the genus Erysiphe, but there was not any report of E. paradoxa in Turkey. The aim of the present research is to make a contribution to the Turkish powdery mildews.

\section{Materials and Methods}

The specimens were collected on $A$. monspessulanum (Montpellier maple) in the northern Slopes of Derebağ waterfall within the borders of Derebağ Town (Kayseri/ Turkey) on October 14, 2015. While infected host surfaces were photographed under stereomicroscope (Euromex BioBlue BB. 1153-PL trinocular stereo microscope with the camera Euromex CMEX-5f DC.
5000F), morphological structures were examined and photographed under a light microscope Zeiss Primo Star binokular microscope with the camera Canon A 300 and the software AxioVision 4.7). Approximately, 30 measurements were taken for each microscopic structure and the compiled data were statistically processed. For SEM analysis, dried pieces of infected Montpellier maple leaves were fixed on stubs using double-sided sticky tape, coated with gold particles, and visualized with an EVO 40XVP (LEO Ltd., Cambridge, UK) scanning electron microscope by using an accelerating voltage of $20 \mathrm{kV}$. The identified samples were kept at the herbarium of Inonu University (INU).

\section{Results}

Systematic overview

Fungi

Ascomycota

Erysiphales

Erysiphaceae

Erysiphe paradoxa (Simonyan) U. Braun \& S. Takam. (Figure 1-2).

Mycelium amphigenous, persistent, thin, effuse. Chasmothecia scattered to gregarious, 100-155(-165) $\mu \mathrm{m}$ diam, peridium cells are irregularly polygonal to rounded, 5-15 $\mu \mathrm{m}$, appendages 30-80, equatorial, flexuouscurved, on aggregated chasmothecia often densely interwoven with each other, widely and loosely curved, sinuous or twisted, length variable, 2-8 times as long as the chasmothecial diam, 3-8 $\mu \mathrm{m}$ wide, aseptate, hyaline, walls thin, somewhat thicker at the base, smooth to rough, apices very widely and loosely uncinate or forming very irregular and loose spirals. Asci 5-12, eassily visible in mature still closed chasmothecia, ellipsoid to ovoid, sessile or short-stalked, 50-80 × 30-50 $\mu \mathrm{m}, \quad 5-8$-spored. Ascospores broadly ellipsoid, ellipsoid to elongate, curved or subcylindrical $20-30 \times 12-18 \mu \mathrm{m}, \mathrm{Q}=(1.3-)$ 1.4-1.6 (-1.7), colorless. Anamorph was not found. 


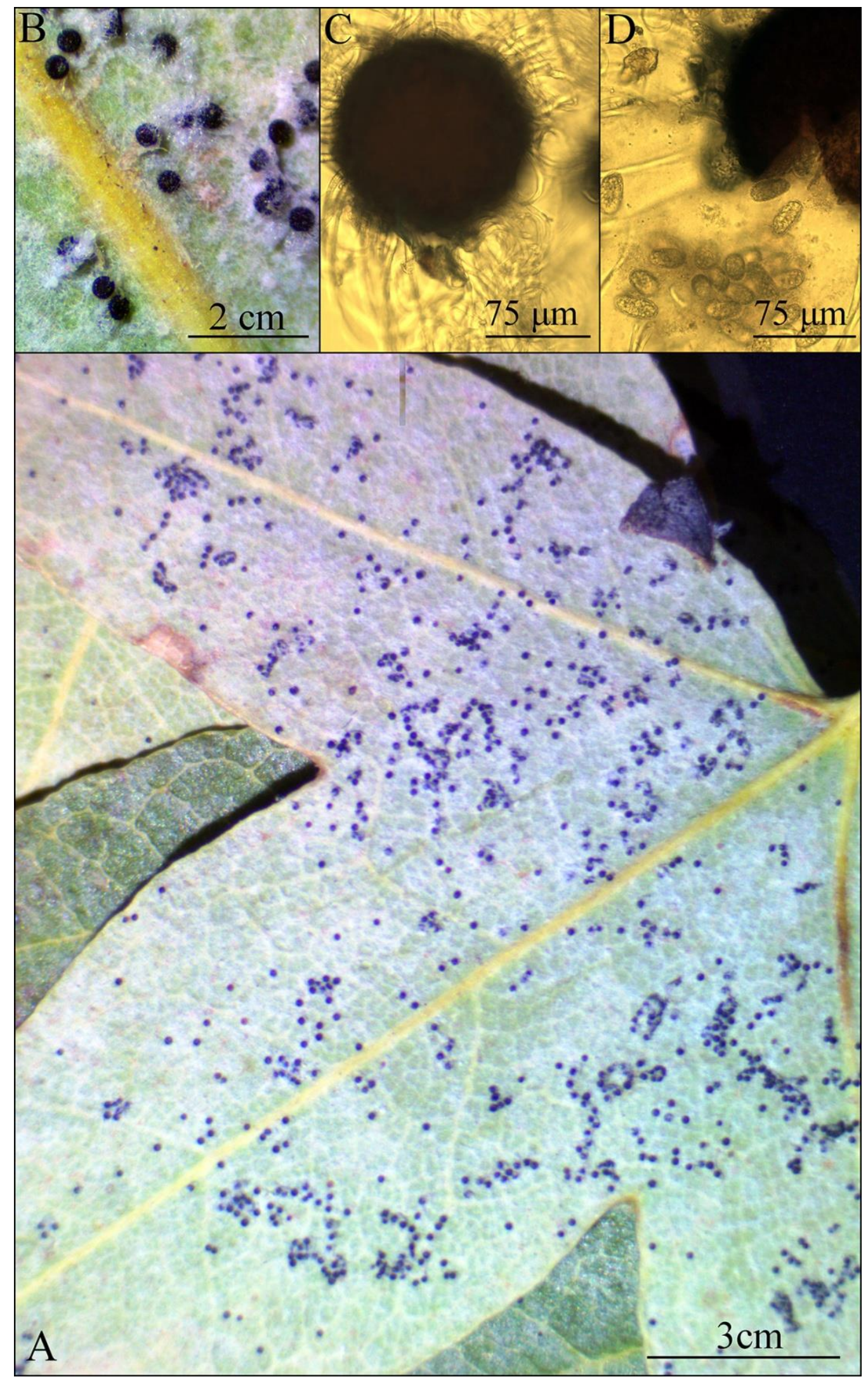

Figure 1. Erysiphe paradoxa on A. monspessulanum: A. the host plant affected by the fungus; $\mathbf{B}$. chasmothecia as viewed under the stereo microscope, $\mathbf{C}$. chasmothecia as viewed under the light microscope, D. asci and ascospores as viewed under the light microscope 


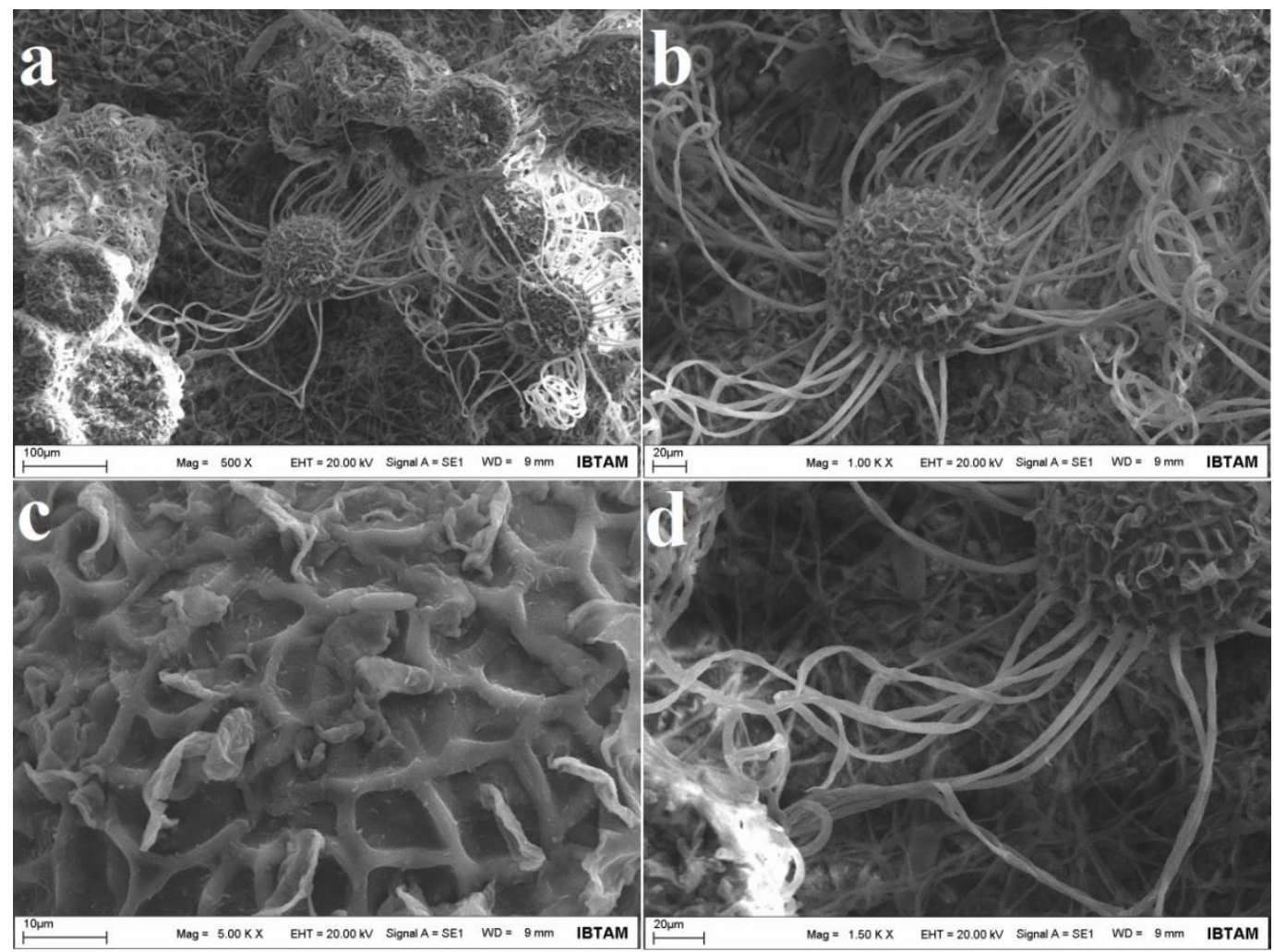

Figure 2. Erysiphe paradoxa on A. monspessulanum as viewed by a scanning electron microscope: A-B chasmothecia, C. peridial surface of the chasmothecia, D. appendages of chasmothecia

\section{Material Examined}

TURKEY - Kayseri: Yahyal1, Northern Slopes of Derebağ waterfall, on Acer monspessulanum L. (Sapindanaceae), 1400 m, 14.10.2015, Kabaktepe \& Akata 8326.

\section{Discussion}

Although numerous powdery mildews are known to grow on maple (Acer) species, only two Erysiphe species, E. ljubarskii (Golovin) U. Braun \& S. Takam. and E. paradoxa prefer maples as host species. These species can easily be distinguished from each other by mycelium, different peridium cells and appendages. While E. paradoxa is an amphigenous species and posseses thin mycelium, irregularly polygonal to rounded, peridium cells (up to $15 \mu \mathrm{m}$ ), appendages (up to $80 \mu \mathrm{m}$ ) with very widely apices which is irregular and loose spiral, E. ljubarskii is mostly epiphyllous, and has polygonal peridium cells (up to $25 \mu \mathrm{m}$ ), appendages(up to $50 \mu \mathrm{m}$ ) with non-enlarged apices which are densely circinate and almost helicoid (Braun and Cook, 2012).
Although morphological features of our Turkish samples match up with the Iranian and Armenian samples of E. paradoxa, our samples have a distinctive characteristics. While peridium cells of Iranian and Armenian samples are obscure, they are conspicuous (irregularly polygonal to rounded, 5-15 $\mu \mathrm{m}$ ) in Turkish samples. (Braun \& Cook, 2012).

With the current study, E. paradoxa on A. monspessulanum was reported for the first time from Turkey and this is the third report (After Armenia and Iran reports) in the World. The species will be the $147^{\text {th }}$ and $49^{\text {th }}$ members of the Turkish powdery mildews and Erysiphe respectively.

\section{Acknowledgements}

We thank TUBITAK (Project no: 113Z093) for its financial support.

\section{References}

Abasova, L. V., Aghayeva, D.N. \& Takamatsu, S. (2018). Notes on powdery mildews of the genus Erysiphe from Azerbaijan. Current Research in Environmental and Applied Mycology, 8(1), 30-53. 
Akata, I. \& Heluta, V.P. (2015). First record of Erysiphe syringae-japonicae in Turkey. Mycotaxon, 130(1), 259-264.

Akata, I., Altuntaş, D. \& Kabaktepe, Ş. (2019) Fungi determined in Ankara University Tandoğan campus area (Ankara-Turkey). Trakya University Journal of Natural Sciences, 20(1), 47-55.

Akdeniz, F. \& Sert, H. (2019). A new host for Podosphaera euphorbiae in Turkey. Journal of New Results in Engineering and Natural Science, 10,16-18.

Braun, U. (1987). A monograph of the Erysiphales. (powdery mildews). Beihefte zur Nova Hedwigia, 89, 1-700.

Braun, U. \& Takamatsu, S. (2000). Phylogeny of Erysiphe, Microsphaera, Uncinula (Erysipheae), and Cystotheca, Podosphaera, Sphaerotheca (Cystotheceae) inferred from rDNA ITS sequences - some taxonomic consequences. Schlechtendalia 4, 1-33.

Braun, U. \& Cook, R.T.A. (2012). Taxonomic manual of the Erysiphales (powdery mildews). CBS Biodiversity Series II, CBS-KHAW Fungal Biodiversity Centre, Utrecht, The Netherlands.

Churakov, B.P., Hüseyin, E., Selçuk, F., Kornilin K.E., Romanova T.A., \& Akgül, H. (2018). Synopsis of powdery mildews biota on forest trees and shrubs of Ulyanovsk region (Russia) and Düzce province (Turkey). Mycology and Phytopathology, 52(1), 30-37.

Heluta, V.P., Akata, I. \& Kabaktepe, Ş. (2017). Erysiphe azaleae, a new powdery mildew fungus introduced into Turkey. Biological Diversity and Conservation, 10(1), 79-83.

Kabaktepe, Ş. \& Akata, I. (2016). A new Erysiphe (Erysiphales) record for Turkey. International Forestry Symposium 07-10 December 2016, Kastamonu, Turkey, 57-59.

Kabaktepe, Ş. \& Akata, I. (2019). The Smut Fungi determined in Aladağlar and Bolkar Mountains (Turkey). The Journal of Fungus, 10(2), 82-86.

Kabaktepe, Ş., Heluta, V.P. \& Akata, I. (2015). Checklist of Powdery mildews (Erysiphales) in Turkey. Biological Diversity and Conservation, 8(3), 128-146.

Khodaparast, S.A. \& Abbasi, M. (2009). Species, host range, and geographical distribution of powdery mildew fungi in Iran. Mycotaxon, 108(1), 213-216.

Simonyan, S.A. (1959). Novy vid muchnistorosyanogo griba iz roda Uncinula, Izvestiya, Akademiya Nauk Armyanskoj SSR. Biologicheskie Nauki, 12(2), 87-88.

Tavanaei, G., Peighami, E. \& Ershad, D. (2000). Uncinula paradoxa, a new record for Mycoflora of Iran. Iranian Journal of Plant Pathology, 36(1-2), 187. 